\title{
Bacterial Endophytes and Their Interactions with Hosts
}

\author{
Mónica Rosenblueth and Esperanza Martínez-Romero \\ Centro de Ciencias Genómicas, Universidad Nacional Autóma de México, Apdo. Postal 565-A, Cuernavaca, México
}

Submitted 9 September 2005. Accepted 8 March 2006.

\begin{abstract}
Recent molecular studies on endophytic bacterial diversity have revealed a large richness of species. Endophytes promote plant growth and yield, suppress pathogens, may help to remove contaminants, solubilize phosphate, or contribute assimilable nitrogen to plants. Some endophytes are seedborne, but others have mechanisms to colonize the plants that are being studied. Bacterial mutants unable to produce secreted proteins are impaired in the colonization process. Plant genes expressed in the presence of endophytes provide clues as to the effects of endophytes in plants. Molecular analysis showed that plant defense responses limit bacterial populations inside plants. Some human pathogens, such as Salmonella spp., have been found as endophytes, and these bacteria are not removed by disinfection procedures that eliminate superficially occurring bacteria. Delivery of endophytes to the environment or agricultural fields should be carefully evaluated to avoid introducing pathogens.
\end{abstract}

Additional keywords: nitrogen fixation, pathogenic bacteria, plant bacteria, plant colonization.

Plants and animals normally associate with diverse microorganisms. In the gut, bacteria have a remarkable role to stimulate immunity and development (Hooper et al. 2001). Similarly plant bacteria stimulate plant defense responses (de Matos Nogueira et al. 2001). Bacteria on roots and in the rhizosphere benefit from root exudates, but some bacteria and fungi are capable of entering the plant as endophytes that do not cause harm and could establish a mutualistic association (Azevedo et al. 2000; Hallmann et al. 1997; Perotti 1926). Plants constitute vast and diverse niches for endophytic organisms. Endophytic bacteria have been isolated from a large diversity of plants as reviewed by Sturz and associates (2000). Plants reported to harbor endophytes are shown in Table 1, but most likely, there is not a single plant species devoid of endophytes. The few examples of apparent absence of internal populations may be because some microorganisms are not easily isolated or cultured.

In general endophytic bacteria occur at lower population densities than rhizospheric bacteria or bacterial pathogens (Hallmann et al. 1997; Rosenblueth and Martínez-Romero 2004). It has not been resolved whether plants benefit more from an endophyte than from a rhizospheric bacterium or if it is more advantageous for bacteria to become endophytic compared with rhizospheric. It is still not always clear which population of microorganisms (endophytes or rhizospheric bacteria) promotes plant growth; nevertheless, benefits conferred by endophytes are well recognized and will be presented here.

Corresponding author: Esperanza Martínez-Romero;

E-mail: emartine@ccg.unam.mx
Endophytic populations, like rhizospheric populations, are conditioned by biotic and abiotic factors (Fuentes Ramírez et al. 1999; Hallmann et al. 1997, 1999; Seghers et al. 2004), but endophytic bacteria could be better protected from biotic and abiotic stresses than rhizospheric bacteria (Hallmann et al. 1997).

Endophytic bacteria in a single plant host are not restricted to a single species but comprise several genera and species. No one knows if communities inside plants interact, and it has been speculated that beneficial effects are the combined effect of their activities. In this review, we will first address the diversity of endophytes. Unfortunately, some of the older papers describing bacteria inside plants have used methods that do not allow an accurate classification of endophytic bacteria.

Criteria to recognize "true" endophytic bacteria have been published (Reinhold-Hurek and Hurek 1998a) and this requires not only the isolation from surface-disinfected tissues but also microscopic evidence to visualize "tagged" bacteria inside plant tissues. The latter criterion is not always fulfilled. Use of the term putative endophytes has been recommended for those not validated microscopically. True endophytes may also be recognized by their capacity to reinfect disinfected seedlings.

Endophytic bacteria have been studied mainly after culturing in laboratory media, but a more complete scheme is emerging, using methods that do not require the bacteria to be cultured and that make use of the analysis of sequences from bacterial genes obtained from DNA isolated from inside plant tissues (Chelius and Triplett 2000a; Engelhard et al. 2000; Miyamoto et al. 2004; Reiter et al. 2003; Sessitsch et al. 2002b). A following molecular approach studying wheat endophytes in Australia revealed a larger diversity of actinobacteria than that obtained by culturing endophytes (Conn and Franco 2004). Evidence that there are endophytic bacteria that have not yet been cultured also comes from the study of citrus endophytes by denaturing gradient gel electrophoresis profiles of $16 \mathrm{~S}$ rRNA gene fragments amplified from total plant DNA. Some bands did not match any of the isolated bacteria grown in culture media (Araujo et al. 2002). In contrast, no differences were obtained by culturing or culture-independent methods and both revealed similar bacteria from the genera Pseudomonas and Rahnella in Norway spruce seeds (Cankar et al. 2005).

\section{Diversity and populations of microorganisms recovered as endophytes.}

Mycorrhizal fungi are ancient plant partners (Simon et al. 1993) widespread among plants. Mycorrhiza benefits to plants are well known but agricultural applications in the field have not frequently led to substantial increases in crop yields. Some trees are incapable of growing without their mycorrhiza, and mycorrhizal fungi are fully dependant on the plant for growth. Recently, host specificity has begun to be recognized, using 
molecular analysis based on the sequence of ribosomal genes (Chelius and Triplett 1999; Jacquot et al. 2000; Kjoller and Rosendahl 2000) and other genes, such as those for actin or elongation factors (Helgason et al. 2003). Interestingly, some mycorrhizal fungi themselves have endosymbiotic bacteria (Glomeribacter gigasporarum; Jargeat et al. 2004). Like my- corrhiza, other endophytic fungi completely depend on the plant and its inside conditions for growth. Some endophytic fungi have been shown to protect plants from herbivores (Schardl et al. 2004) or to be responsible for the synthesis of novel and useful secondary products (Strobel et al. 2004). Rain forest destruction may lead not only to the loss of valuable tree

Table 1. Examples of reported bacterial endophytes and plants harboring them

\begin{tabular}{|c|c|c|}
\hline Endophytes & Plant species & Reference \\
\hline \multicolumn{3}{|l|}{$\alpha$ Proteobacteria } \\
\hline Azorhizobium caulinodans & Rice & Engelhard et al. 2000 \\
\hline Azospirillum brasilense & Banana & Weber et al. 1999 \\
\hline Azospirillum amazonense & Banana, pineapple & Weber et al. 1999 \\
\hline Bradyrhizobium japonicum & Rice & Chantreuil et al. 2000 \\
\hline Gluconacetobacter diazotrophicus & Sugarcane, coffee & Cavalcante and Döbereiner 1988; Jiménez-Salgado et al. 1997 \\
\hline Methylobacterium mesophilicum ${ }^{\mathrm{a}}$ & Citrus plants & Araujo et al. 2002 \\
\hline Methylobacterium extorquens & Scots pine, citrus plants & Araujo et al. 2002; Pirttilä et al. 2004 \\
\hline Rhizobium leguminosarum & Rice & Yanni et al. 1997 \\
\hline Rhizobium (Agrobacterium) radiobacter & Carrot, rice & Surette et al. 2003 \\
\hline Sinorhizobium meliloti & Sweet potato & Reiter et al. 2003 \\
\hline Sphingomonas paucimobilis ${ }^{\mathrm{a}}$ & Rice & Engelhard et al. 2000 \\
\hline \multicolumn{3}{|l|}{$\beta$ Proteobacteria } \\
\hline Azoarcus sp. & Kallar grass, rice & Engelhard et al. 2000; Reinhold-Hurek et al. 1993 \\
\hline Burkholderia pickettii ${ }^{\mathrm{a}}$ & Maize & McInroy and Kloepper 1995 \\
\hline Burkholderia cepacia ${ }^{\mathrm{b}}$ & Yellow lupine, citrus plants & Araujo et al. 2001; Barac et al. 2004 \\
\hline Burkholderia sp. & Banana, pineapple, rice & Weber et al. 1999; Engelhard et al. 2000 \\
\hline Chromobacterium violaceum $^{\mathrm{a}}$ & Rice & Phillips et al. 2000 \\
\hline Herbaspirillum seropedicae & Sugarcane, rice, maize, sorghum, banana & Olivares et al. 1996; Weber et al. 1999 \\
\hline Herbaspirillum rubrisulbalbicans & Sugarcane & Olivares et al. 1996 \\
\hline \multicolumn{3}{|l|}{$\gamma$ Proteobacteria } \\
\hline Citrobacter sp. & Banana & Martínez et al. 2003 \\
\hline Enterobacter spp. & Maize & McInroy and Kloepper 1995 \\
\hline Enterobacter sakazakii ${ }^{\mathrm{a}}$ & Soybean & Kuklinsky-Sobral et al. 2004 \\
\hline Enterobacter cloacae ${ }^{\mathrm{a}}$ & Citrus plants, maize & Araujo et al. 2002; Hinton et al. 1995 \\
\hline Enterobacter agglomerans ${ }^{\mathrm{a}}$ & Soybean & Kuklinsky-Sobral et al. 2004 \\
\hline Enterobacter asburiae & Sweet potato & Asis and Adachi 2003 \\
\hline Erwinia sp. & Soybean & Kuklinsky-Sobral et al. 2004 \\
\hline Escherichia coli ${ }^{\mathrm{b}}$ & Lettuce & Ingham et al. 2005 \\
\hline Klebsiella sp. & Wheat, sweet potato, rice & Engelhard et al. 2000; Iniguez et al. 2004; Reiter et al. 2003 \\
\hline Klebsiella pneumoniae ${ }^{\mathrm{b}}$ & Soybean & Kuklinsky-Sobral et al. 2004 \\
\hline Klebsiella variicola ${ }^{\mathrm{b}}$ & Banana, rice, maize, sugarcane & Rosenblueth et al. 2004. \\
\hline Klebsiella terrigena ${ }^{\mathrm{a}}$ & Carrot & Surette et al. 2003 \\
\hline Klebsiella oxytoca ${ }^{\mathrm{b}}$ & Soybean & Kuklinsky-Sobral et al. 2004 \\
\hline Pantoea sp. & Rice, soybean & Kuklinsky-Sobral et al. 2004; Verma et al. 2004 \\
\hline Pantoea agglomerans & Citrus plants, sweet potato & Araujo et al. 2001, 2002; Asis and Adachi 2003 \\
\hline Pseudomonas chlororaphis & Marigold (Tagetes spp.), carrot & Sturz and Kimpinski 2004; Surette et al. 2003 \\
\hline Pseudomonas putida $a^{\mathrm{a}}$ & Carrot & Surette et al. 2003 \\
\hline Pseudomonas fluorescens & Carrot & Surette et al. 2003 \\
\hline Pseudomonas citronellolis & Soybean & Kuklinsky-Sobral et al. 2004 \\
\hline Pseudomonas synxantha & Scots pine & Prittilä et al. 2004 \\
\hline Salmonella enterica ${ }^{\mathrm{b}}$ & Alfalfa, carrot, radish, tomato & Cooley et al. 2003; Guo et al. 2002; Islam et al. 2004 \\
\hline Serratia sp. & Rice & Sandhiya et al. 2005 \\
\hline Serratia marcescens ${ }^{\mathrm{a}}$ & Rice & Gyaneshwar et al. 2001 \\
\hline Stenotrophomonas ${ }^{\mathrm{a}}$ & $\begin{array}{l}\text { Dune grasses (Ammophila arenaria and } \\
\text { Elymus mollis) }\end{array}$ & Dalton et al. 2004 \\
\hline \multicolumn{3}{|l|}{ Firmicutes } \\
\hline Bacillus spp. & Citrus plants & Araujo et al. 2001, 2002 \\
\hline Bacillus megaterium & Maize, carrot, citrus plants & Araujo et al. 2001; McInroy and Kloepper 1995; Surette et al. 2003 \\
\hline Clostridium & Grass Miscanthus sinensis & Miyamoto et al. 2004 \\
\hline Paenibacillus odorifer & Sweet potato & Reiter et al. 2003 \\
\hline Staphylococcus saprophyticus ${ }^{\mathrm{b}}$ & Carrot, & Surette et al. 2003 \\
\hline \multicolumn{3}{|l|}{ Bacteroidetes } \\
\hline Sphingobacterium sp. ${ }^{\mathrm{a}}$ & Rice & Phillips et al. 2000 \\
\hline \multicolumn{3}{|l|}{ Actinobacteria } \\
\hline Arthrobacter globiformis & Maize & Chelius and Triplett 2000a \\
\hline Curtobacterium flaccumfaciens & Citrus plants & Araujo et al. 2002 \\
\hline Kocuria varians & Marigold & Sturz and Kimpinski 2004 \\
\hline Microbacterium esteraromaticum & Marigold & Sturz and Kimpinski 2004 \\
\hline Microbacterium testaceum & Maize & Zinniel et al. 2002 \\
\hline Mycobacterium sp. ${ }^{\text {b }}$ & Wheat, Scots pine & Conn and Franco 2004; Prittilä et al. 2005 \\
\hline Nocardia sp. ${ }^{\mathrm{b}}$ & Citrus plants & Araujo et al. 2002 \\
\hline Streptomyces & Wheat & Coombs and Franco 2003a \\
\hline
\end{tabular}

a Opportunistic human pathogenic bacteria.

${ }^{\mathrm{b}}$ Common human pathogenic bacteria. 
species but also of unknown endophytes, especially fungi (Strobel et al. 2004). Fungal endophytic interactions will not be further reviewed here, as excellent reviews have been recently published on this topic (Hause and Fester 2005; Schardl et al. 2004; Schulz and Boyle 2005; Strobel and Daisy 2003; Strobel et al. 2004).

Methods for the isolation of bacterial endophytes have been reviewed extensively (Hallmann et al. 1997; Reinhold-Hurek and Hurek 1998a). The use of sodium hypochlorite for disinfecting plant surfaces is common. Residual sodium hypochlorite may affect growth or induce mutagenesis and death of microorganisms, thus making it necessary to rinse the tissues with sodium thiosulfate to remove all the residual sodium hypochlorite (Miché and Balandreau 2001), although this is not a common practice.

A review of published endophytic bacteria was reported by Hallmann and associates in 1997, but the list is no longer complete, as there is much interest in this area and new endophytes are continuously being reported (Table 1).

Remarkably, Salmonella strains have been detected as endophytes in alfalfa sprouts. Outbreaks with these bacteria in alfalfa sprouts have been recorded in North America, Asia and Europe since 1995 (Ponka et al. 1995). It has been proposed that alfalfa plants and seeds be colonized with safe bacteria to out-compete human pathogens. For example, Enterobacter $a b$ suriae was found to eliminate Salmonella enterica and the enterohemorrhagic Escherichia coli from Arabidopsis thaliana seeds (Cooley et al. 2003). It is worrisome that there may be human or opportunistic pathogens among plant endophytes.

It seems that the bacteria best adapted for living inside plants are naturally selected. Endophytes are recruited out of a large pool of soil or rhizospheric species and clones. Indeed, in a large study conducted on potato-associated bacterial communities, species richness and diversity was lower for fungalantagonistic bacteria inside roots than in the rhizosphere of potato (Berg et al. 2005a). Germida and associates (1998) found that the endophytic population was less diverse than the root-surface population and the endophytes appeared to originate from the latter. Mavingui and associates (1992) found that there are different populations of Bacillus polymyxa in soil, rhizosphere, and rhizoplane and that wheat roots select specific populations. Rosenblueth and Martínez-Romero (2004) found, both by multilocus enzyme electrophoresis and by plasmid patterns, that Rhizobium etli strains that were isolated from inside maize stems were selected subsets of the total pool of Rhizobium etli found in rhizosphere, roots, or Phaseolus vulgaris nodules. Rhizobium etli is found as a natural endophyte of maize plants in traditional agricultural fields in which maize and bean are grown in association (Gutiérrez-Zamora and Martínez-Romero 2001). In planta and ex planta populations of Pseudomonas species could be differentiated by biochemical characteristics (van Peer et al. 1990).

Competition experiments with endophytes have shown that some endophytes are more aggressive colonizers and displace others. This was observed with Pantoea sp. out-competing Ochrobactrum sp. in rice (Verma et al. 2004) and with different Rhizobium etli strains in maize (Rosenblueth and Martínez-Romero 2004). However, when the host range of a large diversity of endophytes was analyzed, a seeming lack of strict specificity was observed (Zinniel et al. 2002).

The presence of different endophytic species in soybean depended on the plant genotype, the plant age, the tissue sampled, and also on the season of isolation (Kuklinsky-Sobral et al. 2004). The soil type determined to a large extent the endophytic population in wheat (Conn and Franco 2004). Correlations to growth promotion of tomato plants were observed with inocula levels that promoted endophytic populations but not rhizospheric populations (Pillay and Nowak 1997). On the other hand, the genus Azospirillum, one of the best-characterized plant growth-promoting bacteria, exerts its benefits mainly in the rhizosphere (Somers et al. 2004) and rarely colonizes the plant inner cortical tissues (Schloter and Hartmann 1998; Weber et al. 1999).

The addition of the herbicide glyphosphate produced a modification of the endophytic composition of soybean plants (Kuklinsky-Sobral et al. 2005). Similar results were obtained by inoculating a genetically modified Enterobacter cloacae strain in citrus seedling (Andreote et al. 2004). The analysis by genomic fingerprinting of the diversity of Bacillus pumilus and Pantoea agglomerans isolated from surface-disinfected leaves showed that populations inside citrus do not seem to be clones derived from a single genotype (Araujo et al. 2001).

The population density of endophytes is highly variable, depending mainly on the bacterial species and host genotypes but also in the host developmental stage, inoculum density, and environmental conditions (Pillay and Nowak 1997; Tan et al. 2003). Interestingly, this is also the case with epiphytic (on leaf surface) bacteria, which are highly variable in number, varying around 1,000-fold the population size of one individual bacterial species from leaf to leaf. Total bacterial population sizes on inoculated leaves varied by about 30 -fold (Mercier and Lindow 2000).

Clostridia were detected in surface-disinfected grass leaves, stems, and roots. A group of clostridia was found exclusively in one of the grass species analyzed and not in the surrounding soil (Miyamoto et al. 2004). Some endophytes are very scarce or absent in soil (Reinhold-Hurek and Hurek 1998a).

Endophytic $\mathrm{N}_{2}$-fixing bacteria seem to constitute only a small proportion of total endophytic bacteria (Barraquio et al. 1997; Ladha et al. 1983; Martínez et al. 2003), and increasing $\mathrm{N}_{2}$-fixing populations in plants has been considered as a possibility to increase nitrogen fixation. Nitrogen-fixing bacteria were identified in sweet potato in $\mathrm{N}$-poor soils with an analysis that consisted of amplifying nitrogenase ( if $H$ ) genes by polymerase chain reaction (Reiter et al. 2003). The resulting sequences, presumably derived from endophytes, resembled those from rhizobia, including Sinorhizobium meliloti, Sinorhizobium sp. strain NGR234, and Rhizobium etli. Other detected bacteria were Klebsiella spp. and Paenibacillus odorifer (Reiter et al. 2003). It is interesting that, in this case and perhaps in relation to the methodology used, a dominance of rhizobia was observed, accounting for around $50 \%$ of the sequences obtained. In culture-dependent studies, it seems that fast growing $\gamma$-Proteobacteria out-grow slower-growing $\alpha$-Proteobacteria such as rhizobia.

Endophytic bacteria are found in legume nodules as well. In red clover nodules, some species of rhizobia were found, including Rhizobium (Agrobacterium) rhizogenes, in addition to $R$. leguminosarum bv. trifolii, which is the normal clover symbiont (Sturz et al. 1997). Some $\gamma$-Proteobacteria are cooccupants with the specific rhizobia in Hedysarum plant nodules (Benhizia et al. 2004). In most cases, the endophytic bacteria are unable to form nodules.

\section{Effects of endophytic bacteria and benefits to the plant.}

The growth stimulation by the microorganisms can be a consequence of nitrogen fixation (Hurek et al. 2002; Iniguez et al. 2004; Sevilla et al. 2001) or the production of phytohormones, biocontrol of phytopathogens in the root zone (through production of antifungal or antibacterial agents, siderophore production, nutrient competition and induction of systematic acquired host resistance, or immunity) or by enhancing availability of minerals (Sessitsch et al. 2002a; Sturz et al. 2000). The elucidation of the mechanisms promoting plant growth 
will help to favor species and conditions that lead to greater plant benefits. Volatile substances such as 2-3 butanediol and aceotin produced by bacteria seem to be a newly discovered mechanism responsible for plant-growth promotion (Ryu et al. 2003). It would be interesting to determine if volatiles could be produced inside plants. Endophytes produce adenine ribosides that stimulate growth and mitigate browning of pine tissues (Pirttilä et al. 2004).

Endophytic bacteria of red clover seem to be responsible for the allelopathic effects observed with these plants over maize, causing reduced plant emergence and plant height (Sturz and Christie 1996). For this reason, it was not recommended to grow maize after clover in Canada. Clover endophytic bacteria reproduced the deleterious effects on maize. It would have been more convincing if the authors had tested the effects of clover with and without endophytes on maize germination and development.

A recent review on the mechanisms of biocontrol of plant growth-promoting rhizobacteria includes rhizospheric and endophytic bacteria (Compant et al. 2005). Bacterial endophytes are capable of suppressing nematode proliferation and this may benefit other crops in rotation with the host plants (Sturz and Kimpinski 2004). The frequent isolation of Curtobacterium flaccumfaciens as endophytes from asymptomatic citrus plants infected with the pathogen Xylella fastidiosa suggested that the endophytic bacteria may help citrus plants to better resist the pathogenic infection (Araujo et al. 2002). Endophytes from potato plants showed antagonistic activity against fungi (Berg et al. 2005a; Sessitsch et al. 2004) and also inhibited bacterial pathogens belonging to the genera Erwinia and Xanthomonas (Sessitsch et al. 2004). Some of the endophytic isolates produced antibiotics and siderophores in vitro (Sessitsch et al. 2004).

Inhibition of the oak wilt pathogen Ceratocystis fagacearum was obtained with 183 endophytic bacteria of 889 isolates tested (Brooks et al. 1994). Of 2,648 bacterial isolates analyzed from the rhizosphere, phyllosphere, endosphere, and endorhiza, only one, a root endophyte corresponding to Serratia plymuthica, was a highly effective fungal antagonist (Berg et al. 2005a). Endophytic actinobacteria are effective antagonists of the pathogenic fungus Gaeumannomyces graminis in wheat (Coombs et al. 2004), and several endophytes showed antagonism against Rhizoctonia solani (Parmeela and Johri 2004). It is worth considering that most of the assays to test antagonism are in vitro and it remains to be established if this correlates to effects in nature.

A near-future application may consider the use of geneti cally engineered endophytes with biological control potential in agricultural crops. The endophytes Herbaspirillum serope dicae and Clavibacter xylii have been genetically modified to produce and excrete the $\delta$-endotoxin of Bacillus thuringensis to control insect pests (Downing et al. 2000; Turner et al. 1991).

Bacteria degrading recalcitrant compounds are more abundant among endophytic populations than in the rhizosphere of plants in contaminated sites (Siciliano et al. 2001), which could mean that endophytes have a role in metabolizing these substances. Engineered endophytic Burkholderia cepacia strains improved phytoremediation and promoted plant tolerance to toluene (Barac et al. 2004). There is an increasing interest on genetically modifying endophytes (Andreote et al. 2004). The advantages and obstacles to use bioengineered endophytes have been clearly discussed (Newman and Reynolds 2005; van der Lelie et al. 2004).

Endophytic bacteria possess the capacity to solubilize phosphates, and it was suggested by the authors that the endophytic bacteria from soybean may also participate in phosphate assimilation (Kuklinsky-Sobral et al. 2004).
Brazilian sugarcane plants have been grown for many years with small amounts of fertilizer without showing symptoms of $\mathrm{N}$ deficiencies. Out of the many $\mathrm{N}_{2}$-fixing endophytes isolated from sugarcane, it has not been clearly defined which are responsible for fixing $\mathrm{N}$ inside the plant. However, there is controversy on the level of $\mathrm{N}$ fixed by endophytes and the proportion contributed to the plant (Giller and Merckx 2003). These estimates vary widely in different reports and range from 30 up to $80 \mathrm{~kg} \mathrm{~N} /$ ha/year (Boddey et al. 1995). Under optimal conditions, some plant genotypes seem to obtain part of their $\mathrm{N}$ requirements from nitrogen fixation.

Kallar grass grows in N-poor soils in Pakistan and a diver sity of Azoarcus spp. have been recovered from it (Reinhold-Hurek et al. 1993). Inside wheat, Klebsiella sp. strain Kp342 fixes $\mathrm{N}_{2}$ (Iniguez et al. 2004), and it has been reported that it increases maize yield in the field (Riggs et al 2001). Similarly, nitrogenfixing endophytes seem to relieve $\mathrm{N}$ deficiencies of sweet potato (Ipomoea batatas) in N-poor soils (Reiter et al. 2003).

Grasses growing in nutrient-poor sand dunes contain members of genera Pseudomonas, Stenotrophomonas as well as Burkholderia. It seems that the Burkholderia endophytes could contribute $\mathrm{N}$ to the grasses, because nitrogenase was detected with antibodies in roots within plant cell walls of stems and rhizomas (Dalton et al. 2004).

Some research has been directed to find endophytes that could significantly increase the yields in different crops after their inoculation. To reveal the effects of endophytes, inoculation experiments have been performed, but it has been a problem to eliminate resident or indigenous endophytes from plants in order to have bacteria-free plants or seeds. Functional redundancy of resident endophytes and added inocula may limit the effects observed from inoculation. Very complex microbial community-plant interaction, poor rhizosphere competence with endogenous microorganisms (Sturz et al 2000), and bacterial fluctuations with environmental conditions may also limit the applicability of endophyte inoculation in the field (Sturz and Nowak 2000). Furthermore, in the field, the large abundance and diversity of soil bacteria may be a rich source of endophytes and, for this, inoculation effects may not be observed. Since surface disinfection does not remove endophytes, procedures such as warming and drying seeds have been assayed to diminish bacterial populations inside (Holland and Polacco 1994). Tissue culture has also been used to eliminate or reduce endophytes (Holland and Polacco 1994; Leifert et al. 1994). Inoculants seem to be successful in micropropagated plants, as there are few or no other microorganisms with which to compete. There could be enormous benefits to be gained through the inoculation of microorganisms into soil-less mixes in which plants are transplanted at an early stage in their growth. In such cases, when the plantlets were inoculated, they were more vigorous and had increased drought resistance, an increased resistance to pathogens, less transplanting shock, and lower mortality (Barka et al. 2000; Martínez et al. 2003; Sahay and Varma 1999).

\section{Plant colonization.}

Methylotrophs are seedborne in soybean (Holland and Pollaco 1994). Many seeds carry a diversity of endophytes (Coombs and Franco 2003b; Hallmann et al. 1997). By being seedborne, endophytes assure their presence in new plants. Plants that propagate vegetatively (such as potatoes or sugarcane) can transmit their endophytes to the next generation and would not require the infection process described below. Some pathogens are also found inside seeds (Berg et al. 2005b; Schaad et al. 1995).

In the rhizosphere there is a selection of the microorganisms that are able to survive in the root exudates and compete with 
others. Rosenblueth and Martínez-Romero (2004) found strains that were equally competitive for colonizing the rhizosphere and inside tissues of the root.

In order to colonize the plant, some bacteria must find their way through cracks formed at the emergence of lateral roots or at the zone of elongation and differentiation of the root. Dong and associates (2003) showed that cells of Klebsiella sp/ strain Kp342 aggregate at lateral-root junctions of wheat and alfalfa. Similarly, Gluconacetobacter diazotrophicus and Herbaspirillum seropedicae also colonize lateral-root junctions in high numbers (James and Olivares 1997). Possible infection and colonization sites have been illustrated by Reinhold-Hurek and Hurek (1998b). It has been proposed that cellulolytic and pectinolytic enzymes produced by endophytes are involved in the infection process (Hallmann et al. 1997), as in Klebsiella strains, pectate lyase has been implicated to participate during plant colonization (Kovtunovych et al. 1999). The cell walldegrading enzymes endogluconase and polygalacturonase seem to be required for the infection of Vitis vinifera by Burkholderia sp. (Compant et al. 2005).

In some assays, early endophytic colonization differed from one cultivar to another, but later endophytes were recovered in approximately similar numbers from the different cultivars (Pillay and Nowak 1997). Fungal colonization could affect colonization by endophytic bacteria (Araujo et al. 2001) or the reverse could be true. Strain to strain variation in colonizing capabilities have been found among Rhizobium etli strains (Rosenblueth and Martínez-Romero 2004), and these may be related to differences in genomic content (Rosenblueth et al. unpublished data). In general, endophytic isolates were capable of colonizing or recolonizing the inside plant tissues in higher numbers than isolates from the root surface (van Peer et al. 1990; Rosenblueth and Martínez-Romero 2004).

After 1 day of exposure of certain plant roots to bacteria, they can be found in the aerial parts of the plant. Guo and associates (2002) inoculated the roots of hydroponically grown tomato plants with salmonellae at around $4.55 \log \mathrm{CFU} \mathrm{m}{ }^{-1}$ and, the next day, found that hypocotyls, cotyledons, and stems had around $3 \log \mathrm{CFU} \mathrm{g} \mathrm{g}^{-1}$. The systematic spread of an endophytic Burkholderia strain to aerial parts of Vitis vinifera seems to be through the transpiration stream (Compant et al. 2005).

Solomon and Matthews (2005) irrigated lettuce plants with Escherichia coli 0157:H7 or with fluorescent microspheres (used as bacterial surrogates). After 1, 3, and 5 days, there was no significant difference $(P \leq 0.05)$ in populations between days, but there was significant difference in the internalization of bacteria or fluorescent microspheres. It is remarkable that microspheres attain 100-fold higher levels in plants than do Escherichia coli cells (Solomon and Matthews 2005). The authors suggested that the entry of Escherichia coli into plant roots is not determined by specific bacterial factors but, rather, by the plant.

Endophytes can also play an active role in colonization. Azoarcus sp. type IV pili are involved in the adherence to plant surfaces, an essential step towards endophytic colonization (Dörr et al. 1998). Two Klebsiella strains differ significantly in their invasion capacity in different plant hosts (Medicago sativa, Medicago truncatula, Arabidopsis thaliana, Triticum aestivum, and Oryza sativa). One of them (Kp342) was a better colonizer in all hosts and only needed a single cell to colonize the plants substantially a few days after inoculation (Dong et al. 2003). The plant hosts also differed in their ability to be colonized endophytically by the same bacterium, further suggesting an active host role in the colonization process.

Some rhizospheric bacteria can colonize the internal roots and stems, showing that these bacteria are a source for endo- phytes (Germaine et al. 2004), but also phyllosphere bacteria may be a source of endophytes (Hallmann et al. 1997).

Some flavonoids increased by almost $100 \%$ the number of lateral root cracks colonized in Arabidopsis thaliana by Herbaspirillum seropedicae and Azorhizobium caulinodans (Webster et al. 1998). Colonization of wheat by Azorhizobium caulinodans and Azospirillum brasilense was stimulated by flavonoids (Webster et al. 1998), as was the colonization by Azorhizobium caulinodans of two Brassica napus (oilseed rape) varieties (O'Callaghan et al. 2000). In Rhizobium spp., plant flavonoids were involved in inducing mechanisms to resist plant-defense phytoalexins (González-Pasayo and MartínezRomero 2000; Parniske et al. 1991). Flavonoids are better known for their role in inducing the expression of nod genes that code for enzymes producing Nod factors. Neither Nod genes nor Nod factors are required for the endophytic colonization of Arabidopsis thaliana or wheat (Gough et al. 1997; Webster et al. 1998). Therefore, the role of flavonoids in stimulating colonization may be related to regulating other bacterial genes, such as those for phytoalexin resistance, type III secretion (Perret et al. 1999; Viprey et al. 1998), or genes for the synthesis of lipopolysaccharides (Reuhs et al. 2005), participating in the interaction with the plant. Interestingly, a glucosidase enzyme hydrolyzing glucoside isoflavones was purified from an endophytic Pseudomonas sp. (Yang et al. 2004). This activity could contribute to produce active (aglycone) flavons inside plants, but this has not been tested.

Changes in plant physiology can lead to the development of a distinct endophytic population (Hallmann et al. 1997). A diminished colonization of sugarcane by Gluconacetobacter diazotrophicus was observed in plants under a high nitrogen-fertilization regime as opposed to low $\mathrm{N}$ fertilization. It seems that supplying nitrogen to the plants alters its physiology and may cause a decrease in sucrose, which seems to be used for the endophytic growth (Fuentes-Ramírez et al. 1999). Fertilizer effects over endophytic populations were further confirmed. In rice, a rapid change of the nitrogen-fixing population was observed within 15 days after nitrogen fertilization (Tan et al. 2003). Organic amendments to plants also influence the endophytic populations (Hallmann et al. 1997).

Colonization does not depend on the nitrogen-fixing ability of the bacteria, as $\mathrm{Nif}^{-}$mutants of Gluconacetobacter diazotrophicus or Herbaspirillum seropedicae, were able to colonize as well as $\mathrm{Nif}^{+}$strains (Roncato-Maccari et al 2003; Sevilla et al. 2001). In contrast, Azoarcus mutants affected in pili were incapable of systemic spread into rice shoots (Dörr et al. 1998); this is also the case with mutants unable to produce a secreted endoglucanase (Reinhold-Hurek et al. 2006). Nonmotile mutants of Salmonella enterica were incapable of colonizing or had only a reduced invasion capacity in Arabidopsis thaliana (Cooley et al. 2003).

As plants have a determinant role in controlling endophytic colonization, it is important to avoid performing colonization assays in the laboratory with plants under suboptimal growth conditions, as they may show unbalanced interactions with endophytes with occasional overestimation of bacterial colonization by some strains. An increased diversity of bacterial endophytes was found in Erwinia carotovora-infected potatoes in comparison with noninfected control plants (Reiter et al. 2002). The colonizing capacity may also be overestimated in vitro, as there is no competition with indigenous soil bacteria (Cooley et al. 2003).

\section{Plant location.}

The methods used to assess the occurrence and location of endophytic bacteria have been diverse and include immunological detection of bacteria, fluorescence tags, and confocal 
laser scanning microscopy (Chelius and Triplett 2000b; Hartmann et al. 2000; Verma et al. 2004). In addition, specific oligonucleotide probes could be of use to analyze bacteria inside plants (Hartmann et al. 2000).

Endophytic bacteria are found in roots, stems, leaves, seeds, fruits, tubers, ovules, and also inside legume nodules (Benhizia et al. 2004; Hallmann et al. 1997; Sturz et al. 1997). In most plants, roots have the higher numbers of endophytes compared with above-ground tissues (Rosenblueth and Martínez-Romero 2004).

It seems that the bacterial endophytes described here do not inhabit living vegetal cells (James and Olivares 1997; ReinholdHurek and Hurek 1998a). Intercellular spaces and xylem vessels are the most commonly reported locations for endophytic bacteria (Reinhold-Hurek and Hurek 1998a; Sprent and James 1995). A Burkholderia sp. strain was found in xylem vessels and substomatal chambers in Vitis vinifera plants (Compant et al. 2005). By inhabiting similar niches as vascular pathogens, endophytes may be used as competing bacteria for disease control (Hallmann et al. 1997).

Surface-washing of sprouts was not an effective way to eliminate Salmonella enterica and Escherichia coli strains from alfalfa sprouts or seeds, indicating that these bacteria are located in a protected niche (Cooley et al. 2003). By introducing the green fluorescent protein, their location was defined; Salmonella enterica colonized seed coats and roots, while Escherichia coli colonized only roots (Charkowski et al. 2002).

\section{Molecular interactions.}

In contrast to the extensive information on the molecular mechanisms of other bacteria-plant interactions (Lugtenberg et al. 2002; Oldroyd and Downie 2004), there is only limited data on the endophyte-host molecular interactions.

The plant response. The plant response to endophytes seems to be conditioned, to a large extent, by the plant genotype. Wild races and some plant varieties seem to provide adequate in-plant conditions that stimulate and support nitrogen fixation by endophytes and benefit from it. This has been observed with rice, sugarcane, and maize (Boddey et al. 1995; Engelhard et al. 2000; Gutiérrez-Zamora and Martínez-Romero 2001; Iniguez et al. 2004; Reis et al. 1994; Shrestha and Ladha 1996; Urquiaga et al. 1989).

Plant genes may be modulated by the presence of the bacteria, and the genes so expressed provide clues as to the effects of endophytes in plants. In sugarcane, genes expressed in response to the endophytic colonization of Gluconacetobacter diazotrophicus and Herbaspirillum rubrisubalbicans are being studied (de Matos Nogueira et al. 2001). The sequence analysis of the cDNA and other libraries derived from messenger RNAs expressed in sugarcane when inoculated with Gluconacetobacter diazotrophicus and Herbaspirillum rubrisubalbicans revealed that genes for nitrogen assimilation, for carbon metabolism, for plant growth, as well as genes for a limited plant defense were induced (de Matos Nogueira et al. 2001). Similar strategies could be followed to study the effects of other endophytes in plants.

Arabidopsis thaliana has been used as a model plant to study its interactions with endophytes like Azorhizobium caulinodans and enterobacteria. The advantage of using Arabidopsis thaliana is that there are defined mutants that may be tested for their colonization by endophytes. Iniguez and associates (2005) used Medicago truncatula and Arabidopsis thaliana mutants to determine the role of plant defense-response pathways in regulating the number of endophytic bacteria. They found that ethylene, a signal molecule for induced systemic resistance in plants, decreases endophytic colonization by Klebsiella sp. strain Kp342 and Salmonella enterica serovar Typhi- murium (Salmonella typhimurium) strains. An ethylene-insensitive Medicago truncatula mutant was hypercolonized by Kp342, while the addition of the ethylene precursor 1-aminocyclopropane-1-carboxylic acid to wild-type Medicago truncatula and wheat reduced the amount of endophytic bacteria. By treating the wild-type plants with the ethylene inhibitor 1-methylcyclopropane, a reversion of the reduction of colonization was obtained. Iniguez and associates (2005) also found that the presence of bacterial extracellular components, such as flagella and type III secretion systems (TTSS-SPI1) of Salmonella pathogenicity island 1 decrease endophytic colonization, and Salmonella typhimurium mutants lacking these components have higher endophytic colonization in Medicago sativa and wheat seedlings. Arabidopsis thaliana mutants showed that only a salicylic acid (SA)-independent defense response contributes to restriction of the colonization by Klebsiella sp. strain Kp342. In the case of colonization by Salmonella typhimurium, this is restricted by both SA-dependent and -independent pathways. The study of Salmonella typhimurium flagella mutants suggests that flagella are recognized through the SAindependent response and TTSS-SPI1 is recognized by the SA-dependent response that is involved in inducing the promoter of PRI, a SA-dependent pathogenesis related gene. Kp342 lacks flagella and TTSS-SPI1 (Dong et al. 2001); thus, when it associates with the plant, it does not induce the SAdependent responses and may colonize the plant in higher numbers (Iniguez et al. 2005). Kp342 might have lost its flagella during its evolution in association with plants (Iniguez et al. 2005). Other bacteria that interact closely with plants, such as Rhizobium and Agrobacterium spp., have flagella, but these are not elicitors of plant defense mechanisms (Felix et al. 1999). In plants as well as in mammals and insects, bacterial flagellins are recognized by surface receptors that contain transmembrane proteins with extracellular leucine-rich repeat domains (Gómez-Gómez and Boller 2002). Flagellin acts as an elicitor in whole Arabidopsis thaliana plants, inducing an oxidative burst, callose deposition, and ethylene production and leading to the induction of defense-related genes. Plants can detect the presence of molecules from bacteria through chemoperception systems (Boller 1995).

A local host-defense reaction was induced by an endophytic Burkholderia strain in Vitis vinifera plants (Compant et al. 2005). It remains to be determined if endophytes are affected by innate immunity in plants, as occurs in some animal-bacterial interactions (McPhee et al. 2005). Antimicrobial peptides have been isolated from maize and rice (Duvick et al. 1992) and could have a role in controlling endophytic populations. Limiting carbon sources in the carbon apoplastic fluid may also restrict endophytic growth (Fuentes-Ramírez et al. 1999).

Bacterial genes expressed in the presence of plants. Endophytes may differentially express genes that are required to enter and colonize the plant to grow and survive within plant tissues and to stimulate plant growth, compete and suppress pathogens, or produce different substances.

Endophytic bacteria provide useful and rich models to study the genetic expression of bacteria in their natural niches or habitats (inside plants), which are more structured and variable than culture media under controlled laboratory conditions. Nevertheless, very little work has been done on this. Genomic projects are being performed on some endophytic bacteria, such as Azoarcus spp. (Battistoni et al. 2005), Herbaspirillum sp., Gluconacetobacter diazotrophicus, and Klebsiella spp., which will certainly be of great help to further understand their molecular interaction with plants. In vivo expression technol ogy used to study gene expression in different niches, (Rediers et al. 2005) including the rhizosphere (Ramos-González et al. 2005), may be used as well to study gene expression during endophytic life. 
Roncato-Maccari and associates (2003) examined microscopically a Herbaspirillum seropedicae $\mathrm{Nif}^{+}$strain with a gus A cassette in its nifH gene after inoculation of maize, sorghum, wheat, and rice. They found expression of nif genes in bacterial colonies located in external mucilaginous root material eight days after inoculation, as well as in roots, stems, and leaves. Using a similar approach, Vermeiren and associates (1998) had previously found that nifH gusA fusions of Pseudomonas stutzeri (formerly Alcaligenes faecalis) and Azospirillum irakense were also expressed in rice roots. It was also observed that the NifH (nitrogenase reductase) of Klebsiella pneumoniae occurred in maize roots but not in stems, using an antibody to the purified enzyme (Chelius and Triplett 2000b). In situ hybridization studies demonstrated that Azoarcus nitrogenase genes are expressed inside the roots of field-grown Kallar grass (Hurek et al 1997). These results suggest that grass tissues provide a suitable environment for nitrogen-fixation gene expression, but it seems that $\mathrm{N}_{2}$ fixation in the plant is carbon-limited (Christiansen-Weniger et al 1992). Different grasses inoculated with members of genera Herbaspirillum, Azospirillum, Klebsiella, and Serratia produced ethylene in acetylene reduction assays only when a carbon source was added (Chelius and Triplett 2000b; Egener et al. 1999; Gyaneshwar et al 2002).

Bacteria can communicate through "quorum sensing," a term applied to the production of diffusible signal molecules that control gene expression in a manner dependent upon bacterial population density (quorum) (Swift et al. 1996). Until now, phytopathogenic bacteria have been reported to respond to quorum to produce antibiotics, virulence factors, and plant cell wall-degrading exo-enzymes (Von Bodman et al. 2003). Interestingly, plants can perceive "quorum sensing" signals from the bacteria and control quorum-regulated bacterial responses (Bauer and Mathesius 2004; Mathesius et al. 2003). It would be interesting to determine if endophytes produce "quorum sensing" molecules inside plants and the effects they cause. Inside the plant, there could be exchange of signal molecules among microorganisms and of bacteria with the host, although this has not yet been reported.

It would also be interesting to address whether some of the well-studied molecular mechanisms used by phytopathogenic bacteria (Van't Slot and Knogge 2002) are to some extent shared with endophytes.

\section{May endophytes be or become pathogens?}

Most fungal grass endophytes are considered mutualistic with their hosts. The main advantage for the plants is the protection they confer against herbivory by toxic alkaloids (Schardl et al. 2004). These fungal endophytes, like bacteria, may obtain nutrients from the plant and protection from abiotic stresses like desiccation. But some fungal endophytes (Stone et al. 2000) may become plant pathogens, depending on the developmental stage of host and fungus, environmental factors, and host defense responses (Schulz and Boyle 2005). It was frequently found that some bacterial endophytic isolates from healthy plants inhibited the growth of tomato seedlings in reinoculation assays, possibly through the production of certain metabolites (van Peer et al. 1990). Some endophytes seem to be latent pathogens, and infections may proceed under certain conditions. These may be due to changes in environmental conditions such as $\mathrm{CO}_{2}$ accumulation or $\mathrm{O}_{2}$ depletion (Lund and Wyatt 1972), but others could be related to the presence of other microorganisms interacting with the endophyte. There are reports that mixed inoculations of two endophytic bacteria that individually inhibit growth result in plant-growth promotion (Sturz et al. 1997). The order in which endophytic populations are inoculated and become established in the host plant could affect subsequent plant-growth promotion effects (Sturz and Christie 1995). Herbaspirillum rubrisubalbicans may cause a mild mottled stripe disease in a few sugarcane varieties but give no symptoms in most hosts (James et al. 1997; Olivares et al. 1997). It seems there is an equilibrium of endophytes and plants that under certain circumstances may be unbalanced to the detriment of one of the partners.

In other cases, endophytes have been found to be closely related to human pathogens or are either human or opportunistic human pathogens. This is the case of endophytic Salmonella strains, which have caused outbreaks and constitute a health risk for consumers of raw fruits and vegetables (Guo et al. 2002), and of the Burkholderia cepacia strains isolated from plants (Barac et al. 2004). As Burkholderia cepacia causes pulmonary infection (even fatal) in human cystic fibrosis patients, a reassessment of the risk and a moratorium on the agricultural use of Burkholderia strains have been suggested (Holmes et al. 1998; Parke and Gurian-Sherman 2001). Approaches to reduce raw vegetable contamination produced by pathogens propose strategies to increase the number of safe growth-promoting bacteria in plants (Iniguez et al. 2005).

Nocardia endophytes have been isolated from members of genus Citrus. Some Nocardia species are known to be human pathogens causing nocardiasis (a severe human infection in feet and legs that may lead to amputation) that is transmitted by soil. A fluctuating and prominent population of Mycobacterium spp. was found in Scots pine that seemed to be required for bud development. When the tissue was fully developed, the endophyte was no longer detected (Pirttilä et al. 2005). Мyсоbacterium isolates related to those reported as clinical isolates were the most frequently encountered in wheat in Australia (Conn and Franco 2004). It was not analyzed whether these mycobacteria carry some virulence genes.

Parke and Gurian-Sherman (2001) stated "It is not coincidental perhaps that many of the most effective biocontrol agents (Stenotrophomonas maltophilia, Pantoea agglomerans, ... and Burkholderia cepacia) of plant diseases are also opportunistic human pathogens. These ... are fiercely competitive for nutrients and may produce antimicrobial metabolites and may themselves be resistant to multiple antibiotics." In addition, surviving plant defense reactions may render endophytic bacteria resistant to human defense responses as well. Some endophytes have been found to contain genes that are required for virulence in pathogens (Barak et al. 2005; Dörr et al. 1998). It has been difficult to differentiate environmental isolates and clinical bacteria of Pseudomonas spp. (Foght et al. 1996). This is the case with plant endophytes from rice, sugarcane, banana, and maize (Martínez et al. 2003) and clinical isolates from hospitals in Mexico (Rosenblueth et al. 2004) and in Europe (Brisse and Verhoef 2001). All these were classified as Klebsiella variicola (Rosenblueth et al. 2004). Although Klebsiella variicola seems to be less virulent than Klebsiella pneumoniae and has different epidemiological dynamics (Martínez et al. 2004), its use in agriculture was discouraged (Lloret et al. 2004). Even if some plant bacterial lineages may be distinguished from pathogenic lineages, their close genetic relatedness may render the former good recipients to acquire virulence genes by lateral transfer from their pathogenic relatives. Still very little is known of the genetic behavior of bacteria and the frequency of transfer of genes in natural habitats.

\section{Perspectives.}

The natural condition of plants seems to be in a close interaction with endophytes. Endophytes seem promising to increase crop yields, remove contaminants, inhibit pathogens, and produce fixed nitrogen or novel substances. The repertoire of their 
effects and functions in plant has not been comprehensively defined. The challenge and goal is to be able to manage microbial communities to favor plant colonization by beneficial bacteria. This would be amenable when a better knowledge on endophyte ecology and their molecular interactions is attained. The contributions of this research field may have economic and environmental impacts.

\section{ACKNOWLEDGMENTS}

Thanks to J. Martínez for technical support and to M. Dunn and P. Vinuesa for reading the manuscript. Partial financial support was from CONACyT grant 40997-Q.

\section{LITERATURE CITED}

Andreote, F. D., Gullo, M. J., de Souza Lima, A. O., Junior, W. M., Azevedo, J. L., and Araujo, W. L. 2004. Impact of genetically modified Enterobacter cloacae on indigenous endophytic community of Citrus sinensis seedlings. J. Microbiol. 42:169-173.

Araujo, W. L., Maccheroni, W., Jr., Aguilar-Vildoso, C. I., Barroso, P. A. V., Saridakis, H. O., and Azevedo, J. L. 2001. Variability and interactions between endophytic bacteria and fungi isolated from leaf tissues of citrus rootstocks. Can. J. Microbiol. 47:229-236.

Araujo, W. L., Marcon, J., Maccheroni, W., Jr., Van Elsas, J. D., Van Vuurde, J. W. L., and Azevedo, J. L. 2002. Diversity of endophytic bacterial populations and their interaction with Xylella fastidiosa in citrus plants. Appl. Environ. Microbiol. 68:4906-4914.

Asis, C. A., and Adachi, K. 2003. Isolation of endophytic diazotroph Pantoea agglomerans and nondiazotroph Enterobacter asburiae from sweet potato stem in Japan. Lett. Appl. Microbiol. 38:19-23.

Azevedo, J. L., Maccheroni, W., Jr., Pereira, J. O., and de Araujo, W. L. 2000. Endophytic microorganisms: A review on insect control and recent advances on tropical plants. Electron. J. Biotechnol. Vol. 3, No. 1. Online publication.

Barac, T., Taghavi, S., Borremans, B., Provoost, A., Oeyen, L., Colpaert, J. V., Vangronsveld, J., and van der Lelie, D. 2004. Engineered endophytic bacteria improve phytoremediation of water-soluble, volatile, organic pollutants. Nat. Biotechnol. 22:583-588.

Barak, J. D., Gorski, L., Naraghi-Arani, P., and Charkowski, A. O. 2005. Salmonella enterica virulence genes are required for bacterial attachment to plant tissue. Appl. Environ. Microbiol. 71:5685-5691.

Barka, E. A., Belarbi, A., Hachet, C., Nowak, J., and Audran, J. C. 2000. Enhancement of in vitro growth and resistance to gray mould of Vitis vinifera co-cultured with plant growth-promoting rhizobacteria. FEMS (Fed. Eur. Microbiol. Soc.) Microbiol. Lett. 186:91-95.

Barraquio, W. L., Revilla, L., and Ladha, J. K. 1997. Isolation of endophytic diazotrophic bacteria from wetland rice. Plant Soil 194:15-24.

Battistoni, F., Bartels, D., Kaiser, O., Marie Reamon-Buettner, S., Hurek, T., and Reinhold-Hurek, B. 2005. Physical map of the Azoarcus sp. strain BH72 genome based on a bacterial artificial chromosome library as a platform for genome sequencing and functional analysis. FEMS (Fed. Eur. Microbiol. Soc.) Microbiol. Lett. 249:233-240.

Bauer, W. D., and Mathesius, U. 2004. Plant responses to bacterial quorum sensing signals. Curr. Opin. Plant Biol. 7:429-433.

Benhizia, Y., Benhizia, H., Benguedouar, A., Muresu, R., Giacomini, A., and Squartini, A. 2004. Gamma proteobacteria can nodulate legumes of the genus Hedysarum. Syst. Appl. Microbiol. 27:462-468.

Berg, G., Krechel, A., Ditz, M., Sikora, R. A., Ulrich, A., and Hallmann, J. 2005. Endophytic and ectophytic potato-associated bacterial communities differ in structure and antagonistic function against plant pathogenic fungi. FEMS (Fed. Eur. Microbiol. Soc.) Microbiol. Ecol. $51: 215-229$

Berg, T., Tesoriero, L., and Hailstones, D. L. 2005. PCR-based detection of Xanthomonas campestris pathovars in Brassica seed. Plant Pathol. 54:416-427.

Boddey, R. M., de Oliveira, O. C., Urquiaga, S., Reis, V. M., Olivares, F. L., Baldani, V. L. D., and Döbereiner, J. 1995. Biological nitrogen fixation associated with sugar cane and rice: Contributions and prospects for improvement. Plant Soil 174:195-209.

Boller, T. 1995. Chemoperception of microbial signals in plant cells. Annu. Rev. Plant Physiol. Plant Mol. Biol. 46:189-214.

Brisse, S., and Verhoef, J. 2001. Phylogenetic diversity of Klebsiella pneumoniae and Klebsiella oxytoca clinical isolates revealed by randomly amplified polymorphic DNA, gyrA and parC genes sequencing and automated ribotyping. Int. J. Syst. Evol. Microbiol. 51:915-924.

Brooks, D. S., González, C. F., Appel, D. N., and Filer, T. H. 1994. Eval- uation of endophytic bacteria as potential biological control agents for oak wilt. Biol. Control 4:373-381.

Cankar, K., Kraigher, H., Ravnikar, M., and Rupnik, M. 2005. Bacterial endophytes from seeds of Norway spruce (Picea abies L. Karst) FEMS (Fed. Eur. Microbiol. Soc.) Microbiol. Lett. 244:341-345.

Cavalcante, V. A., and Döbereiner, J. 1988. A new acid-tolerant nitrogen fixing bacterium associated with sugarcane. Plant Soil 108:23-31.

Charkowski, A. O., Barak, J. D., Sarreal, C. Z., and Mandrell, R. E, 2002. Differences in growth of Salmonella enterica and Escherichia coli O157:H7 on alfalfa sprouts. Appl. Environ. Microbiol. 68:3114-3120.

Chaintreuil, C., Giraud, E., Prin, Y., Lorquin, J., Ba, A., Gillis, M., de Lajudie, P., and Dreyfus, B. 2000. Photosynthetic bradyrhizobia are natural endophytes of the African wild rice Oryza breviligulata. Appl. Environ. Microbiol. 66:5437-5447.

Chelius, M. K., and Triplett, E. W. 1999. Rapid detection of arbuscular mycorrhizae in roots and soil of an intensively managed turf grass system by PCR amplification of small subunit rDNA. Mycorrhiza 9:61-64.

Chelius, M. K., and Triplett, E. W. 2000a. Diazotrophic endophytes associated with maize. Pages 779-791 in: Prokaryotic Nitrogen Fixation; A Model System for Analysis of a Biological Process. Horizon Scientific Press, Wymondham, U.K.

Chelius, M. K., and Triplett, E. W. 2000b. Immunolocalization of dinitrogenase reductase produced by Klebsiella pneumoniae in association with Zea mays L. Appl. Environ. Microbiol. 66:783-787.

Christiansen-Weniger, C., Groneman, A. F., and van Veen, J. A. 1992. Associative $\mathrm{N}_{2}$ fixation and root exudation of organic acids from wheat cultivars of different aluminum tolerance. Plant Soil 139:167-174.

Compant, D., Duffy, B., Nowak, J., Clément, C., Barka, E. A. 2005. Use of plant growth-promoting bacteria for biocontrol of plant diseases: Principles, mechanisms of action, and future prospects. Appl. Eviron. Microbiol. 71:4951-4959.

Compant, S., Reiter, B., Sessitsch, A., Nowak, J., Clement, C., and Ait Barka, E. 2005. Endophytic colonization of Vitis vinifera L. by plant growth-promoting bacterium Burkholderia sp. strain PsJN. Appl. Environ. Microbiol. 71:1685-1693.

Conn, V. M., and Franco, C. M. M. 2004. Analysis of the endophytic actinobacterial population in the roots of wheat (Triticum aestivum L.) by terminal restriction fragment length polymorphism and sequencing of 16S rRNA clones. Appl. Environ. Microbiol. 70:1787-1794.

Cooley, M. B., Miller, W. G., and Mandrell, R. E. 2003. Colonization of Arabidopsis thaliana with Salmonella enterica and enterohemorrhagic Escherichia coli 0157:H7 and competition by Enterobacter asburiae. Appl. Environ. Microbiol. 69:4915-4926.

Coombs, J. T., and Franco, C. M. M. 2003a. Isolation and identification of actinobacteria isolated from surface-sterilized wheat roots. Appl. Environ. Microbiol. 69:5303-5308.

Coombs, J. T., and Franco, C. M. M. 2003b. Visualization of an endophytic Streptomyces species in wheat seed. Appl. Environ. Microbiol. 69:4260-4262.

Coombs, J. T., Michelsen, P. P., and Franco, C. M. M. 2004. Evaluation of endophytic actinobacteria as antagonists of Gaeumannomyces graminis var. tritici in wheat. Biol. Control 29:359-366.

Dalton, D. A., Kramer, S., Azios, N., Fusaro, S., Cahill, E., and Kennedy, C. 2004. Endophytic nitrogen fixation in dune grasses (Ammophila arenaria and Elymus mollis) from Oregon. FEMS (Fed. Eur. Microbiol. Soc.) Microbiol. Ecol. 49:469-479.

de Matos Nogueira, E., Vinagre, F., Masuda, H. P., Vargas, C., de Pádua, V. L. M.., da Silva, F. R., dos Santos, R. V., Baldani, J. I., Gomes Ferreira, P. C., and Hemerley. 2001. Expression of sugarcane genes induced by inoculation with Gluconacetobacter diazotrophicus and Herbaspirillum rubrisubalbicans. Genet. Mol. Biol. 24:199-206.

Dong, Y., Glasner, J. D., Blattner, F. R., and Triplett, E. W. 2001. Genomic interspecies microarray hybridization: Rapid discovery of three thousand genes in the maize endophyte, Klebsiella pneumoniae 342 , by microarray hybridization with Escherichia coli K-12 open reading frames. Appl. Environ. Microbiol. 67:1911-1921.

Dong, Y., Iniguez, A. L., and Triplett, E. W. 2003. Quantitative assessments of the host range and strain specificity of endophytic colonization by Klebsiella pneumoniae 342. Plant Soil 257:49-59.

Dörr, J., Hurek, T., and Reinhold-Hurek, B. 1998. Type IV pili are involved in plant-microbe and fungus-microbe interactions. Mol. Microbiol. 30:7-17.

Downing, K. J., Leslie, G., and Thomson, J. A. 2000. Biocontrol of the sugarcane borer Eldana saccharina by expression of the Bacillus thuringiensis cry1 Ac7 and Serratia marcescens chiA genes in sugarcane-associated bacteria. Appl. Environ. Microbiol. 66:2804-2810.

Duvick, J. P., Rood, T., Raro, A. G., and Marshak, D. R. 1992. Purification and characterization of a novel antimicrobial peptide from maize (Zea mays L.) kernels. J. Biol. Chem. 267:18814-18820.

Egener, T., Hurek, T., and Reinhold-Hurek, B. 1999. Endophytic expres- 
sion of nif genes of Azoarcus sp. strain BH72 in rice roots. Mol. PlantMicrobe Interactions 12:813-819.

Engelhard, M., Hurek, T., and Reinhold-Hurek, B. 2000. Preferential occurrence of diazotrophic endophytes, Azoarcus spp., in wild rice species and land races of Oryza sativa in comparison with modern races. Environ. Microbiol. 2:131-41.

Felix, G., Duran, J. D., Volko, S., and Boller, T. 1999. Plants have a sensitive perception system for the most conserved domain of bacterial flagellin. Plant J. 18:265-276.

Foght, J. M., Westlake, D. W. S., Johnson, W. M., and Ridgway, H. F. 1996. Environmental gasoline-utilizing isolates and clinical isolates of Pseudomonas aeruginosa are taxonomically indistinguishable by chemotaxonomic and molecular techniques. Microbiology 142:23332340.

Fuentes-Ramírez, L. E., Caballero-Mellado, J., Sepúlveda, J., and Martínez-Romero, E. 1999. Colonization of sugarcane by Acetobacter diazotrophicus is inhibited by high $\mathrm{N}$-fertilization. FEMS (Fed. Eur. Microbiol. Soc.) Microbiol. Ecol. 29:117-128.

Germaine, K., Keogh, E., Garcia-Cabellos, G., Borremans, B., Van der Lelie, D., Barac, T., Oeyen, L., Vangronsveld, J., Moore, F. P., Moore, E. R. B., Campbell, C. D., Ryan, D., and Dowling, D. N. 2004. Colonisation of poplar trees by $g f p$ expressing bacterial endophytes. FEMS (Fed. Eur. Microbiol. Soc.) Microbiol. Ecol. 48:109-118.

Germida, J. J., Siciliano, S. D., De Freitas, J. R., and Seib, A. M. 1998. Diversity of root-associated bacteria associated with field-grown canola (Brassica napus L.) and wheat (Triticum aestivum L.). FEMS (Fed. Eur. Microbiol. Soc.) Microbiol. Ecol. 26:43-50.

Giller, K. E., and Merckx, R. 2003. Exploring the boundaries of $\mathrm{N}_{2}$-fixation in cereals and grasses: An hypothetical and experimental framework. Symbiosis 35:3-17.

Gómez-Gómez, L., and Boller, T. 2002. Flagellin perception: A paradigm for innate immunity. Trends Plant Sci. 7:251-256.

González-Pasayo, E., and Martínez-Romero, E. 2000. Multiresistance genes of Rhizobium etli CFN42. Mol. Plant-Microbe Interact. 13:572577.

Gough, C., Galera, C., Vasse, J., Webster, G., Cocking, E. C., and Denarie, J. 1997. Specific flavonoids promote intercellular root colonization of Arabidopsis thaliana by Azorhizobium caulinodans ORS571. Mol. Plant-Microbe Interact. 10:560-70.

Guo, X., van Iersel, M. W., Chen, J., Brackett R. E., and Beuchat, L R. 2002. Evidence of association of salmonellae with tomato plants grown hydroponically in inoculated nutrient solution. Appl. Environ. Microbiol. 68:3639-3643

Gutiérrez-Zamora, M. L., and Martínez-Romero, E. 2001. Natural endophytic association between Rhizobium etli and maize (Zea mays L.). J. Biotechnol. 91:117-126.

Gyaneshwar, P., James, E. K., Mathan, N., Reddy, P. M., Reinhold-Hurek, B., and Ladha, J. K. 2001. Endophytic colonization of rice by a diazotrophic strain of Serratia marcescens. J. Bacteriol. 183:2634-2645.

Gyaneshwar, P., James, E. K., Reddy, P. M., and Ladha, J. K. 2002. Herbaspirillum colonization increases growth and nitrogen accumulation in aluminum-tolerant rice varieties. New Phytol. 154:131-145.

Hallmann, J., Quadt-Hallmann, A., Mahaffee, W. F., and Kloepper, J. W. 1997. Bacterial endophytes in agricultural crops. Can. J. Microbiol 43:895-914

Hallmann, J., Rodriguez-Kabana, R., and Kloepper, J. W. 1999. Chitinmediated changes in bacterial communities of the soil, rhizosphere and within roots of cotton in relation to nematode control. Soil Biol. Biochem. 31:551-560.

Hartmann, A., Stoffels, M., Eckert, B., Kirchhof, G., and Schloter, M 2000. Analysis of the presence and diversity of diazotrophic endophytes. Pages 727-736 in: Prokaryotic Nitrogen Fixation: A Model System for Analysis of a Biological Process. Horizon Scientific Press, Wymondham, U.K.

Hause, B., and Fester, T. 2005. Molecular and cell biology of arbuscular mycorrhizal symbiosis. Planta 221:184-196.

Helgason, T., Watson, I. J., and Young, J. P. W. 2003. Phylogeny of the Glomerales and Diversisporales (Fungi: Glomeromycota) from actin and elongation factor 1-alpha sequences. FEMS (Fed. Eur. Microbiol. Soc.) Microbiol. Lett. 229:127-132.

Hinton, D. M., and Bacon, C. W. 1995. Enterobacter cloacae is an endophytic symbiont of corn. Mycopathologia. 129:117-125.

Holland, M. A., and Polacco, J. C. 1994. PPFMs and other covert contaminants: Is there more to plant physiology than just plant? Annu. Rev. Plant Physiol. Plant Mol. Biol. 45:197-209.

Holmes, A., Govan, J., and Goldstein, R. 1998. Agricultural use of Burkholderia (Pseudomonas) cepacia: A threat to human health? Emerg. Infect. Dis. 4:221-227.

Hooper, L. V., Wong, M. H., Thelin, A., Hansson, L., Falk, P. G., and Gordon, J. I. 2001. Molecular analysis of commensal host-microbial re- lationships in the intestine. Science 291:881-884.

Hurek, T., Egener, T., and Reinhold-Hurek, B. 1997. Divergence in nitrogenases of Azoarcus spp., Proteobacteria of the beta subclass. J. Bacteriol. 179:4172-4178.

Hurek, T., Handley, L. L., Reinhold-Hurek, B., and Piche, Y. 2002. Azoarcus grass endophytes contribute fixed nitrogen to the plant in an unculturable state. Mol. Plant-Microbe Interact. 15:233-242.

Ingham, S. C., Fanslau, M. A., Engel, R. A., Breuer, J. R., Breuer, J. E., Wright, T. H., Reith-Rozelle, J. K., Zhu, J. 2005. Evaluation of fertilization-to-planting and fertilization-to-harvest intervals for safe use of noncomposted bovine manure in Wisconsin vegetable production. J. Food Prot. 68:1134-1142.

Iniguez, A. L., Dong, Y., Carter, H. D., Ahmer, B. M. M., Stone, J. M., Triplett, E. W. 2005. Regulation of enteric endophytic bacterial colonization by plant defenses. Mol. Plant-Microbe Interact. 18:169-178.

Iniguez, A. L., Dong, Y., and Triplett, E. W. 2004. Nitrogen fixation in wheat provided by Klebsiella pneumoniae 342. Mol. Plant-Microbe Interact. 17:1078-1085

Islam, M., Morgan, J., Doyle, M. P., Phatak, S. C., Millner, P., and Jiang, X. 2004. Fate of Salmonella enterica serovar Typhimurium on carrots and radishes grown in fields treated with contaminated manure composts or irrigation water. Appl. Environ. Microbiol. 70:2497-2502.

Jacquot, E., van Tuinen, D., Gianinazzi, S., and Gianinazzi-Pearson, V. 2000. Monitoring species of arbuscular mycorrhizal fungi in plants and in soil by nested PCR: Application to the study of the impact of sewage sludge. Plant Soil 226:179-188.

James, E. K., and Olivares, F. B. 1997. Infection and colonization of sugar cane and other graminaceous plants by endophytic diazotrophs. Crit. Rev. Plant Sci. 17:77-119.

James, E. K., Olivares, F. L., Baldani, J. I., and Döbereiner, J. 1997. Herbaspirillum, an endophytic diazotroph colonizing vascular tissue in leaves of Sorghum bicolor L. Moench. J. Exp. Bot. 48:785-797.

Jargeat, P., Cosseau, C., Ola'h, B., Jauneau, A., Bonfante, P., Batut, J., and Becard, G. 2004. Isolation, free-living capacities, and genome structure of "Candidatus Glomeribacter gigasporarum," the endocellular bacterium of the mycorrhizal fungus Gigaspora margarita. J. Bacteriol. 186:6876-6884

Jiménez-Salgado, T., Fuentes-Ramirez, L. E., Tapia-Hernandez, A., Mascarua-Esparza, M. A., Martinez-Romero, E., and CaballeroMellado, J. 1997. Coffea arabica 1., a new host plant for Acetobacter diazotrophicus, and isolation of other nitrogen-fixing acetobacteria. Appl. Environ. Microbiol. 63:3676-3683.

Kjoller, R., and Rosendahl, S. 2000. Detection of arbuscular mycorrhizal fungi (Glomales) in roots by nested PCR and SSCP (single stranded conformation polymorphism). Plant Soil 226:189-196.

Kovtunovych, G., Lar, O., Kamalova, S., Kordyum, V., Kleiner, D., and Kozyrovska, N. 1999. Correlation between pectate lyase activity and ability of diazotrophic Klebsiella oxytoca VN 13 to penetrate into plant tissues. Plant Soil 215:1-6.

Kuklinsky-Sobral, J., Araujo, W. L., Mendes, R., Geraldi, I. O., PizziraniKleiner, A. A., and Azevedo, J. L. 2004. Isolation and characterization of soybean-associated bacteria and their potential for plant growth promotion. Environ. Microbiol. 6:1244-1251.

Kuklinsky-Sobral, J., Araújo, W. L., Mendes, R., Pizzirani-Kleiner, A. A., and Azevedo, J. L. 2005. Isolation and characterization of endophytic bacteria from soybean (Glycine max) grown in soil treated with glyphosate herbicide. Plant Soil 273:91-99.

Ladha, J. K., Barraquio, W. L., and Watanabe, I. 1983. Isolation and identification of nitrogen-fixing Enterobacter cloacae and Klebsiella planticola associated with rice plants. Can. J. Microbiol. 29:1301-1308.

Leifert, C., Morris, C. E., and Waites, W. M., 1994. Ecology of microbial saprophytes and pathogens in tissue culture and field-grown plants: Reasons for contamination problems in vitro. Crit. Rev. Plant Sci. 13:139-183.

Lloret, L., Rosenblueth, M., Toledo, I., and Martínez Romero, E. 2004. Ecología bacteriana. Beneficios y riesgos del uso agrícola de rizobios y klebsiellas. Sci. Am. Lat. Am. 3:34-35.

Lugtenberg, B. J. J., Chin-A-Woeng, T. F. C., and Bloemberg, G. V. 2002. Microbe-plant interactions: Principles and mechanisms. Antonie van Leeuwenhoek 81:373-383.

Lund, B. M., and Wyatt, G. M. 1972. The effect of oxygen and carbon dioxide concentrations on bacterial soft rot of potatoes. I. King Edward potatoes inoculated with Erwinia carotovora var. atroseptica. Potato Res. 15:174-179.

Martínez, J., Martínez, L., Rosenblueth, M., Silva, J., and MartínezRomero, E. 2004. How are gene sequence analyses modifying bacterial taxonomy? The case of Klebsiella. Intl. Microbiol. 7:261-268.

Martínez, L., Caballero, J., Orozco, J., and Martínez-Romero, E. 2003. Diazotrophic bacteria associated with banana (Musa spp.). Plant Soil 257:35-47. 
Mathesius, U., Mulders, S., Gao, M., Teplitski, M., Caetano-Anolles, G., Rolfe, B. G., and Bauer, W. D. 2003. Extensive and specific responses of a eukaryote to bacterial quorum-sensing signals. Proc. Natl. Acad. Sci. U.S.A. 100:1444-1449.

Mavingui, P., Laguerre, G., Berge, O., and Heulin, T. 1992. Genetic and phenotypic diversity of Bacillus polymyxa in soil and in the wheat rhizosphere. Appl. Environ. Microbiol. 58:1894-1903.

McPhee, J. B., Scott, M. G., and Hancock, R. E. 2005. Design of host defence peptides for antimicrobial and immunity enhancing activities. Comb. Chem. High T. Scr. 8:257-272.

McInroy, J. A., and Kloepper, J. W. 1995. Survey of indigenous bacterial endophytes from cotton and sweet corn. Plant Soil 173:337-342.

Mercier, J., and Lindow, S. E. 2000. Role of leaf surface sugars in colonization of plants by bacterial epiphytes. Appl. Environ. Microbiol. 66:369-374.

Miché, L., and Balandreau, J. 2001. Effects of rice seed surface disinfection with hypochlorite on inoculated Burkholderia vietnamiensis. Appl. Environ. Microbiol. 67:3046-3052.

Miyamoto, T., Kawahara, M., and Minamisawa, K. 2004. Novel endophytic nitrogen-fixing clostridia from the grass Miscanthus sinensis as revealed by terminal restriction fragment length polymorphism analysis. Appl. Environ. Microbiol. 70:6580-6586.

Newman, L. A., and Reynolds, C. M. 2005. Bacteria and phytoremediation: New uses for endophytic bacteria in plants. Trends Biotechnol. 23:6-8.

O’Callaghan, K. J., Stone, P. J., Hu, X., Griffiths, D. W., Davey, M. R., and Cocking, E. C. 2000. Effects of glucosinolates and flavonoids on colonization of the roots of Brassica napus by Azorhizobium caulinodans ORS571. Appl. Environ. Microbiol. 66:2185-2191.

Oldroyd, G. E. D., and Downie, J. A. 2004. Calcium, kinases and nodulation signaling in legumes. Nat. Rev. Mol. Cell Biol. 5:566-576.

Olivares, F. L., Baldani, V. L. D., Reis, V. M., Baldani, J. I., and Dobereiner, J. 1996. Occurrence of the endophytic diazotrophs Herbaspirillum spp. in roots, stems, and leaves, predominantly of Gramineae. Biol. Fertil. Soils 21:197-200.

Olivares, F. L., James, E. K., Baldani, J. I., and Döbereiner, J. 1997. Infection of mottled stripe disease-susceptible and resistant sugar cane varieties by the endophytic diazotroph Herbaspirillum. New Phytol. 135:723-737.

Parke, J. L., and Gurian-Sherman, D. 2001. Diversity of the Burkholderia cepacia complex and implications for risk assessment of biological control strains. Annu. Rev. Phytopathol. 39:225-258.

Parmeela and Johri, B. N. 2004. Phylogenetic analysis of bacterial endophytes showing antagonism against Rhizoctonia solani. Current Science 87:687-692.

Parniske, M., Ahlborn, B., and Werner, D. 1991. Isoflavonoid-inducible resistance to the phytoalexin glyceollin in soybean rhizobia. J. Bacteriol. 173:3432-3439.

Perotti, R. 1926. On the limits of biological enquiry in soil science. Proc. Int. Soc. Soil Sci. 2:146-161.

Perret, X., Freiberg, C., Rosenthal, A., Broughton, W. J., and Fellay, R. 1999. High-resolution transcriptional analysis of the symbiotic plasmid of Rhizobium sp. NGR234. Mol. Microbiol. 32:415-425.

Phillips, D. A., Martínez-Romero, E., Yang, G. P., and Joseph, C. M. 2000 Release of nitrogen: A key trait in selecting bacterial endophytes for agronomically useful nitrogen fixation. Pages 205-217 in: The Quest for Nitrogen Fixation in Rice. J. K. Ladha and P. M. Reddy (eds.). International Rice Research Institute, Manila, The Philippines.

Pillay, V. K., and Nowak, J. 1997. Inoculum density, temperature, and genotype effects on in vitro growth promotion and epiphytic and endophytic colonization of tomato (Lycopersicon esculentum L.) seedlings inoculated with a pseudomonad bacterium. Can. J. Microbiol. 43:354361.

Pirttilä, A. M., Joensuu, P., Pospiech, H., Jalonen, J., and Hohtola, A. 2004. Bud endophytes of Scots pine produce adenine derivatives and other compounds that affect morphology and mitigate browning of callus cultures. Physiol. Plantarum 121:305-312.

Pirttilä, A. M., Pospiech, H., Laukkanen, H., Myllylä, R., and Hohtola, A. 2005. Seasonal variations in location and population structure of endophytes in buds of Scots pine. Tree Physiol. 25:289-297.

Ponka, A., Andersson, Y., Siitonen, A., de Jong, B., Jahkola, M., Haikala, O., Kuhmonen, A., and Pakkala, P. 1995. Salmonella in alfalfa sprouts. Lancet 345:462-3.

Ramos-Gonzalez, M. I., Campos, M. J., and Ramos, J. L. 2005. Analysis of Pseudomonas putida KT2440 gene expression in the maize rhizosphere: In vivo expression technology capture and identification of root-activated promoters. J. Bacteriol. 187:4033-4041.

Rediers, H., Rainey, P. B., Vanderleyden, J., and De Mot, R. 2005. Unraveling the secret lives of bacteria: Use of in vivo expression technology and differential fluorescence induction promoter traps as tools for ex- ploring niche-specific gene expression. Microbiol. Mol. Biol. Rev. 69:217-261.

Reinhold-Hurek, B., and Hurek, T. 1998a. Interactions of gramineous plants with Azoarcus spp. and other diazotrophs: Identification, localization, and perspectives to study their function. Crit. Rev. Plant Sci. 17:29-54.

Reinhold-Hurek, B., and Hurek, T. 1998b. Life in grasses: Diazotrophic endophytes. Trends Microbiol. 6:139-44.

Reinhold-Hurek, B., Hurek, T., Gillis, M., Hoste, B., Vancanneyt, M., Kersters, K., and De-Ley, J. 1993. Azoarcus gen. nov., nitrogen-fixing proteobacteria associated with roots of Kallar grass (Leptochloa fusca (L.) Kunth), and description of two species, Azoarcus indigens sp. nov. and Azoarcus communis sp. nov. Int. J. Syst. Bacteriol. 43:574-584.

Reinhold-Hurek, B., Maes, T., Gemmer, S., Van Montagu, M., and Hurek, T. 2006. An endoglucanase is involved in infection of rice roots by the not-cellulose-metabolizing endophyte Azoarcus sp. strain BH72. Mol. Plant-Microbe Interact. 19:181-188.

Reis, V. M., Olivares, F. L., and Döbereiner, J. 1994. Improved methodology for isolation of Acetobacter diazotrophicus and confirmation of its endophytic habitat. World J. Microbiol. Biotechnol. 10:401-405.

Reiter, B., Bürgmann, H., Burg, K., and Sessitsch, A. 2003. Endophytic nifH gene diversity in African sweet potato. Can. J. Microbiol. 49:549555.

Reiter, B., Pfeifer, U., Schwab, H., and Sessitsch, A. 2002. Response of endophytic bacterial communities in potato plants to infection with Erwinia carotovora subsp. atroseptica. Appl. Environ. Microbiol. 68:2261-2268.

Reuhs, B.L., Relic, B., Forsberg, L. S., Marie, C., Ojanen-Reuhs, T. Stephens, S. B., Wong, C.-H., Jabbouri, S., and Broughton, W. J. 2005 Structural characterization of a flavonoid-inducible Pseudomonas aeruginosa a-band-like $\mathrm{O}$ antigen of Rhizobium sp. strain NGR234, required for the formation of nitrogen-fixing nodules. J. Bacteriol. 187:6479-6487.

Riggs, P. J., Chelius, M. K., Iniguez, A. L., Kaeppler, S. M., and Triplett, E. W. 2001. Enhanced maize productivity by inoculation with diazotrophic bacteria. Aust. J. Plant Physiol. 28:829-836.

Roncato-Maccari, L. D. B., Ramos, H. J. O., Pedrosa, F. O., Alquini, Y., Chubatsu, L. S., Yates, M. G., Rigo, L. U., Steffens, M. B. R., and Souza, E. M. 2003. Endophytic Herbaspirillum seropedicae expresses nif genes in gramineous plants. FEMS (Fed. Eur. Microbiol. Soc.) Microbiol. Ecol. 45:39-47.

Rosenblueth, M., Martinez, L., Silva, J., and Martinez-Romero, E. 2004. Klebsiella variicola, a novel species with clinical and plant-associated isolates. Syst. Appl. Microbiol. 27:27-35.

Rosenblueth, M., and Martinez Romero, E. 2004. Rhizobium etli maize populations and their competitiveness for root colonization. Arch. Microbiol. 181:337-344.

Ryu, C.-M., Farag, M. A., Hu, C. -H., Reddy, M. S., Wei, H. -X., Pare, P. W., and Kloepper, J. W. 2003. Bacterial volatiles promote growth in Arabidopsis. Proc. Natl. Acad. Sci. U.S.A. 100:4927-4932.

Sahay, N. S., and Varma A. 1999. Piriformospora indica: A new biological hardening tool for micropropagated plants. FEMS (Fed. Eur. Microbiol Soc.) Microbiol. Lett. 181:297-302.

Sandhiya, G. S., Sugitha, T. C. K., Balachandar, D., and Kumar, K. 2005. Endophytic colonization and in planta nitrogen fixation by a diazotrophic Serratia sp. in rice. Indian J. Exp. Biol. 43:802-807.

Schaad, N. W., Cheong, S. S., Tamaki, S., Hatziloukas, E., and Panopoulos, N. J. 1995. A combined biological and enzymatic amplification (BIO-PCR) technique to detect Pseudomonas syringae pv. phaseolicola in bean seed extracts. Phytopathology 85:243-246.

Schardl, C. L., Leuchtmann, A., and Spiering, M. J. 2004. Symbioses of grasses with seedborne fungal endophytes. Ann. Rev. Plant Biol. 55:315-340.

Schloter, M., and Hartmann, A. 1998. Endophytic and surface colonization of wheat roots (Triticum aestivum) by different Azospirillum brasilense strains studied with strain-specific monoclonal antibodies. Symbiosis 25:159-179.

Schulz, B., and Boyle, C. 2005. The endophytic continuum. Mycol. Res. 109:661-686.

Seghers, D., Wittebolle, L., Top, E. M., Verstraete, W., and Siciliano, S. D. 2004. Impact of agricultural practices on the Zea mays L. endophytic community. Appl. Environ. Microbiol. 70:1475-1482.

Sessitsch, A., Howieson, J. G., Perret, X, Antoun, H., and MartínezRomero, E. 2002a. Advances in Rhizobium research. Crit. Rev. Plant Sci. 21:323-378.

Sessitsch, A., Reiter, B., Pfeifer, U., and Wilhelm, E. 2002b. Cultivationindependent population analysis of bacterial endophytes in three potato varieties based on eubacterial and Actinomycetes-specific PCR of $16 \mathrm{~S}$ rRNA genes. FEMS (Fed. Eur. Microbiol. Soc.) Microbiol. Ecol. 39:2332. 
Sessitsch, A., Reiter, B., and Berg, G. 2004. Endophytic bacterial communities of field-grown potato plants and their plant-growth-promoting and antagonistic abilities. Can. J. Microbiol. 50:239-249.

Sevilla, M., Burris, R. H., Gunapala, N., and Kennedy, C. 2001. Comparison of benefit to sugarcane plant growth and ${ }^{15} \mathrm{~N}_{2}$ incorporation following inoculation of sterile plants with Acetobacter diazotrophicus wildtype and Nif $^{-}$mutants strains. Mol. Plant-Microbe Interact. 14:358-366.

Shrestha, R. K., and Ladha, J. K. 1996. Genotypic variation in promotion of rice dinitrogen fixation as determined by nitrogen-15 dilution. Soil. Sci. Soc. Am. J. 60:1815-1821.

Siciliano, S. D., Fortin, N., Mihoc, A., Wisse, G., Labelle, S., Beaumier, D., Ouellette, D., Roy, R., Whyte, L., G., Banks, M., K., Schwab, P., Lee, K., and Greer, C. W. 2001. Selection of specific endophytic bacterial genotypes by plants in response to soil contamination. Appl. Environ. Microbiol. 67:2469-2475.

Simon, L., Bousquet, J., Levesque, R. C., and Lalonde, M. 1993. Origin and diversification of endomycorrhizal fungi and coincidence with vascular land plants. Nature. 363:67-69.

Solomon, E. B., and Matthews K. R. 2005. Use of fluorescent microspheres as tool to investigate bacterial interactions with growing plants. J. Food Prot. 68:870-873.

Somers, E., Vanderleyden, J., and Srinivasan, M. 2004. Rhizosphere bacterial signaling: A love parade beneath our feet. Crit. Rev. Microbiol. 30:205-240

Sprent, J. I., and James, E. K. 1995. $\mathrm{N}_{2}$-fixation by endophytic bacteria: Questions of entry and operation. Pages 15-30 in: Azospirillum VI and Related Microorganisms. I. Fendrik, M. del Gallo, J. Vanderleyden, M. de Zamaroczy (eds.). Springer-Verlag, Berlin.

Stone, J. K., Bacon, C. W., and White, J. F. 2000. An overview of endophytic mibrobes: Endophytism defined. Pages 3-30 in: Microbial Endophytes. C. W. Bacon, and J. F. White (eds.). Marcel Dekker, New York.

Strobel, G., and Daisy, B. 2003. Bioprospecting for microbial endophytes and their natural products. Microbiol. Mol. Biol. Rev. 67:491-502.

Strobel, G., Daisy, B., Castillo, U., and Harper, J. 2004. Natural products from endophytic microorganisms. J. Nat. Prod. 67:257-268.

Sturz, A. V., and Christie, B. R. 1995. Endophytic bacterial systems governing red clover growth and development. Ann. Appl. Biol. 126:285290

Sturz, A. V., and Christie, B. R. 1996. Endophytic bacteria of red clover as agents of allelopathic clover-maize syndromes. Soil Biol. Biochem. 28:583-588

Sturz, A. V., Christie, B. R., Matheson, B. G., and Nowak, J. 1997. Biodiversity of endophytic bacteria which colonize red clover nodules, roots, stems and foliage and their influence on host growth. Biol. Fertil. Soils 25:13-19.

Sturz, A. V., Christie, B. R., and Nowak, J. 2000. Bacterial endophytes: Potential role in developing sustainable systems of crop production. Crit. Rev. Plant Sci. 19:1-30.

Sturz, A., and Kimpinski, J. 2004. Endoroot bacteria derived from marigolds (Tagetes spp.) can decrease soil population densities of rootlesion nematodes in the potato root zone. Plant Soil 262:241-249.

Sturz, A. V., and Nowak, J. 2000. Endophytic communities of rhizobacteria and the strategies required to create yield enhancing associations with crops. Appl. Soil Ecol. 15:183-190.

Surette, M. A., Sturz, A. V., Lada, R. R., and Nowak, J. 2003. Bacterial endophytes in processing carrots (Daucus carota L. var. sativus): Their localization, population density, biodiversity and their effects on plant growth. Plant Soil 253:381-390.

Swift, S., Throup, J. P., Williams, P., Salmond, G. P., and Stewart, G. S
1996. Quorum sensing: A population-density component in the determination of bacterial phenotype. Trends Biochem. Sci. 21:214-219.

Tan, Z., Hurek, T., and Reinhold-Hurek, B. 2003. Effect of N-fertilization, plant genotype and environmental conditions on nifH gene pools in roots of rice. Environ. Microbiol. 5:1009-1015.

Turner, J. T., Lampel, J. S., Stearman, R. S., Sundin, G. W., Gunyuzlu, P., and Anderson, J. J. 1991. Stability of the $\delta$-endotoxin gene from Bacillus thuringiensis subsp. kurstaki in a recombinant strain of Clavibacter xyli subsp. cynodontis. Appl. Environ. Microbiol. 57:3522-3528.

Urquiaga, S. Botteon, P. B. L., and Boddey, R. M. 1989. Selection of sugar cane cultivars for associated biological nitrogen fixation using ${ }^{15} \mathrm{~N}-\mathrm{la}$ beled soil. Pages 311-319 in: Nitrogen Fixation with Non-Legumes. A. Skinner (ed.). Kluwer Academic Publishers, Dordrecht, The Netherlands.

van der Lelie, D., Barac, T., Taghavi, S., and Vangrosveld, J. 2004. Response to Newman: New uses of endophytic bacteria to improve phytoremediation. Trends Biotechnol. 23:8-9.

van Peer, R., Punte, H. L. M., de Weger, L. A., and Schippers, B. 1990. Characterization of root surface and endorhizosphere pseudomonads in relation to their colonization of roots. Appl. Environ. Microbiol. 56:2462-2470.

Van't Slot, K. A. E., and Knogge, W. 2002. A dual role for microbial pathogen-derived effector proteins in plant disease and resistance. Crit. Rev. Plant Sci. 21:229-271.

Verma, S. C., Singh, A., Chowdhury, S. P., and Tripathi, A. K. 2004. Endophytic colonization ability of two deep-water rice endophytes, Pantoea sp. and Ochrobactrum sp. using green fluorescent protein reporter. Biotechnol. Lett. 26:425-429.

Vermeiren, H., Vanderleyden, J., and Hai, W. L. 1998. Colonization and nifH expression on rice roots by Alcaligenes faecalis A15. Pages $167-$ 177 in: Nitrogen Fixation with Non-Legumes. K. A. Malik, M. S. Mirza, and J. K. Ladha, eds.. Kluwer Academic Publishers, London.

Viprey, V., Del Greco, A., Golinowski, W., Broughton, W. J., and Perret, X. 1998. Symbiotic implications of type III protein secretion machinery in Rhizobium. Mol. Microbiol. 28:1381-1389.

Von Bodman, S. B., Bauer, W. D., and Coplin, D. L. 2003. Quorum sensing in plant-pathogenic bacteria. Annu. Rev. Phytopathol. 41:455-482.

Weber, O. B., Baldani, V. L. D., Teixeira, K. R. S., Kirchhof, G., Baldani, J. I., and Dobereiner, J. 1999. Isolation and characterization of diazotrophic bacteria from banana and pineapple plants. Plant Soil 210:103113.

Webster, G., Jain, V., Davey, M. R., Gough, C., Vasse, J., Denarie, J., and Cocking, E. C. 1998. The flavonoid naringenin stimulates the intercellular colonization of wheat roots by Azorhizobium caulinodans. Plant Cell Environ. 21:373-383.

Yang, L., Ning, Z. S., Shi, C. Z., Chang, Z. Y., and Huan, L. Y. 2004. Purification and characterization of an isoflavone-conjugates-hydrolyzing $\beta$-glucosidase from an endophytic bacterium. J. Agric. Food Chem. 52:1940-1944.

Yanni, Y. G., Rizk, R. Y., Corich, V., Squartini, A., Ninke, K., PhilipHollingsworth, S., Orgambide, G., De Bruijn, F., Stoltzfus, J., Buckley, D., Schmidt, T. M., Mateos, P. F., Ladha, J. K., and Dazzo, F. B. 1997. Natural endophytic association between Rhizobium leguminosarum bv. trifolii and rice roots and assessment of potential to promote rice growth. Plant Soil 194:99-114.

Zinniel, D. K., Lambrecht, P., Harris, N. B., Feng, Z., Kuczmarski, D., Higley, P., Ishimaru, C. A., Arunakumari, A., Barletta, R. G, and Vidaver, A. K. 2002. Isolation and characterization of endophytic colonizing bacteria from agronomic crops and prairie plants. Appl. Environ Microbiol. 68:2198-2208. 